\title{
Mesin Penerjemah Interaktif Dengan Animasi 3D Berbasis Augmented Reality
}

\author{
Arbi Haza Nasution ${ }^{1}$, Yoze Rizki ${ }^{2}$, Salhazan Nasution ${ }^{3}$, Rafi Muhammad ${ }^{1}$ \\ Teknik Informatika, Universitas Islam Riau, Indonesia ${ }^{1}$, \\ Teknik Informatika, Universitas Muhammadiyah Riau, Indonesia ${ }^{2}$ \\ Teknik Informatika, Universitas Riau, Indonesia ${ }^{3}$ \\ arbi@eng.uir.ac.id,yozerizki@umri.ac.id,salhazan@lecturer.unri.ac.id,rafimuhammad2612@gmail.com
}

\begin{tabular}{l}
\hline Article Info \\
\hline History: \\
Dikirim 19 Juli 2019 \\
Direvisi 26 Juli 2019 \\
Diterima 5 Agustus 2019 \\
\hline
\end{tabular}

\section{Kata Kunci:}

MesinPenerjemah Augmented Reality Chatbot

\begin{abstract}
Abstrak
Bahasa Inggris adalah salah satu bahasa yang digunakan sebagai alat komunikasi universal, karenanya tanpa kemampuan bahasa Inggris seseorang akan mengalami kesulitan berkomunikasi secara baik dan benar pada ruang lingkup internasional. Penelitian ini mengembangkan aplikasi mesin penerjemah berbasis augmented reality yang dapat memberikan edukasi kepada siswa dengan media yang berbeda agar meningkatkan minat siswa dalam belajar bahasa Inggris. Aplikasi ini menggunakan library vuforia sdk yang mampu menampilkan karakter 3 dimensi dengan teknik markerless dalam bentuk augmented reality. Hasil akhir dari penelitian ini berupa aplikasi yang dapat digunakan pada smartphone dengan sistem operasi android, berdasarkan hasil pengujian terhadap aplikasi didapat kesimpulan bahwa aplikasi ini dapat menampilkan karakter 3 dimensi pada cahaya yang redup dengan intensitas cahaya 28 lux pada jarak $10 \mathrm{~cm}-60 \mathrm{~cm}$ dan sudut penglihatan $10^{\circ}-90^{\circ}$, setelah dilakukan peninjauan terhadap aplikasi $99 \%$ koresponden menyatakan aplikasi ini baik, maka aplikasi ini dapat membantu siswa mempelajari kembali bahasa Inggris selain di sekolah.

(c) This work is licensed under a Creative Commons AttributionShareAlike 4.0 International License.
\end{abstract}

\footnotetext{
Koresponden:

Arbi Haza Nasution,

Teknik Informatika, Fakultas Teknik

Universitas Islam Riau

Jl. KaharuddinNasution 113 Pekanbaru Riau

Email: arbi@eng.uir.ac.id
}

\section{PENDAHULUAN}

Perkembangan terknologi informasi saat ini membuat semua negara berkembang meningkatkan kualitas sumber daya manusia (SDM) nya dalam upaya menghadapi persaingan global [1]. Bahasa Inggris adalah salah satu bahasa yang digunakan sebagai alat komunikasi universal pada ruang lingkup internasional. Saat ini bahasa Inggris merupakan bahasa asing yang diperkenalkan di sekolah dasar karena anak-anak usia 6-12 tahun memiliki masa belajar cemerlang yang disebut golden age [2]. Sarana pembelajaran disekolah saat ini masih konvensional guru menyampaikan pelajaran di depan kelas dibantu dengan buku paket sebagai panduan mengajar, hal tersebut membuat siswa kurang tertarik dalam proses pembelajaran.

Penelitian ini merealisasikan sebuah sistem berupa sarana edukasi pembelajaran bahasa Inggris yang dirancang menarik untuk menambah minat belajar anak di usia sekolah. Sistem ini 
menerjemahan dari teks ke suara dalam bahasa Indonesia ke bahasa Inggris dan sebaliknya. Dibutuhkan smartphone sebagai media untuk menjalankan aplikasi. Karakter dalam bentuk 3 dimensi akan menerjemahkan pertanyaan dari pengguna baik itu kata atau kalimat yang sudah diinputkan sebelumnya.

\section{TINJAUAN PUSTAKA}

Penelitian pertama yang menjadi rujukan berjudul "Aplikasi Pembelajaran Bahasa Inggris Untuk Murid Sekolah Dasar Berbasis Android" [2]. Aplikasi pembelajaran bahasa Inggris untuk murid sekolah dasar berbasis android ini merupakan aplikasi pembelajaran yang dapat digunakan secara interaktif dalam memahami kosa kata sederhana yang dapat dimengerti oleh siswa dalam mempelajari bahasa Inggris sesuai dengan standar kompetensi siswa-siswa kelas 1, aplikasi ini terdiri dari beberapa materi yaitu Number (angka), Times (waktu), People Around Us (orang disekitar kita), dan Daily Activities (kegiatan sehari-hari). aplikasi ini terdiri dari beberapa kategori dan kosa kata yang terbatas dalam pembelajaran, karena aplikasi hanya ditujukan untuk pengenalan huruf, angka, kegiatan sehari-hari, dan orang disekitar kita. Aplikasi tersebut dibangun menggunakan android studio 2.3.1, dimana android studio adalah sebuah Integrated Development Environment (IDE) untuk pengembang aplikasi android. Ada banyak fitur dari aplikasi android tersebut karena memiliki beberapa plugin yang sangat membantu yaitu Gradle yang tentu saja tidak didapatkan di IDE eclipse yang notabene adalah produk lama google.

Dari uraian diatas dapat disimpulkan bahwa perbedaan penelitian ini dengan penelitian tersebut terletak pada implementasi sistem serta ide penelitian nya, dimana pada penelitian sebelumnya hanya fokus pada pengenalan vocabulary dan listening, kosakata dan objek yang digunakan juga terbatas. Sedangkan pada penelitian ini, sistem dapat menerjemahkan setiap kata atau kalimat yang diinput kan oleh pengguna baik dalam bahasa Indonesia ke bahasa Inggris atau tanpa ada keterbatasan dalam kosa kata. Ditambah lagi penerjemahan dilakukan oleh karakter 3 dimensi.

Penelitian kedua yang menggunakan augmented reality sudah dilakukan sebelumnya dengan teknik markerless. Penelitian kedua dengan judul "Implementasi Augmented Reality (AR) Pada Fosil Purbakala di Museum Geologi Bandung" bertujuan untuk menampilkan infomasi secara real time di layar ponsel yang digunakan oleh pengunjung [3]. Metode pengenalan gambarnya menggunakan metode Markerless Augmented Reality, dimana gambar diambil melalui kamera ponsel pengunjung. Dengan metode Markerless inilah informasi dari beberapa bentuk tulang fosil yang tidak utuh akan ditampilkan dengan wujud yang sebenarnya. Pembuatan aplikasi tersebut menggunakan Vuforia SDK sebagai tools library dari Augmented Reality dan Unity3D sebagai tools game engine untuk menghasilkan model animasi yang telah dibuat. Perbedaan penelitan yang dilakukan oleh Yoga Aprillion Saputra dengan penelitian ini terletak pada ide penelitian, objek penelitian dan tools untuk membangun Augmented Reality.

Penelitian selanjutnya berjudul "Pengembangan Aplikasi Respon Sms Dan Panggilan Telepon Menggunakan Android Text To Speech Dan Proximity Sensor Bagi Pengemudi Mobil" [4]. Penelitian ini merupakan implementasi dan akan menghasilkan rancang bangun aplikasi respons sms dan panggilan telepon bagi pengemudi mobil berbasis android. Aplikasi tersebut menggunakan proximity sensor untuk meningkatkan akurasi dalam menerima respon. Dalam penelitian ini juga digunakan teknologi text to speech (TTS) versi 1.6. Teknologi TTS memungkinkan perangkat untuk menerjemahkan ucapan/suara menjadi teks. Teknologi TTS dapat membaca notifikasi sms dan telepon masuk dengan baik walaupun dalam kondisi offline. Sistem dirancang untuk memudahkan pengguna untuk memilih pesan dan mengirim sms dengan modul kata kunci. Dari uraian diatas dapat di simpulkan bahwa perbedaan penelitian ini dengan penelitian tersebut terletak pada objek penelitian, tool yang digunakan serta penerapan sistem yang akan dibuat.

\subsection{Mesin Penerjemah}

Menapaki sejarah mesin penerjemah dapat digolongkan menjadi tiga jenis berdasarkan perkembangannya, yaitu mesin penerjemah berbasis aturan / rule-base machine translatation (RBMT), mesin penerjemah berbasis statistic / statistical machine translation (SMT), dan mesin penerjemah berbasis jaringan saraf tiruan / neural machine translation (NMT). Mesin penerjemah berbasis statistic dan mesin penerjemah berbasis jaringan saraf tiruan membutuhkan korpus 
berkualitas tinggi, sedangkan mesin penerjemah berbasis aturan membutuhkan kamus dwibahasa, penganalisa morfologi, sintaks, dan makna. Sumber daya bahasa tersebut sangat langka untuk bahasa dengan sumber daya rendah seperti bahasa Indonesia, karena kurangnya sumber daya bahasa, sulit untuk membuat mesin penerjemah dari bahasa dengan sumber daya tinggi menuju bahasa dengan sumber daya rendah seperti bahasa daerah Indonesia, namun demikian, karakteristik bahasa daerah Indonesia yang banyak memiliki kemiripan kosa-kata memotivasi peneliti sebelumnya untuk membuat mesin penerjemah hibrida berbasis poros / pivot-based hybrid machine translation (PHMT) $[5,6]$ yang menggabungkan SMT dan RBMT dengan bahasa Indonesia sebagai bahasa poros.

\subsection{Pivot-based Hybrid Machine Translation}

Layanan Google Translate dan layanan kamus dwibahasa dapat digabungkan menjadi layanan komposit pada Language Grid, sebuah media untuk berbagi sumber daya bahasa [5, 6]. Language grid yang didirikan untuk membuat alat kolaborasi yang disesuaikan untuk mendukung masyarakat multibahasa, telah meningkatkan layanan berbasis web untuk masyarakat di seluruh dunia dengan menyediakan akses ke berbagai sumber daya bahasa dan juga menyediakan infrastruktur yang sangat mudah untuk diadaptasikan dengan sistem yang sudah tersedia [7]. Ada lebih dari seratus sumber daya bahasa yang tersedia di layanan Google Translate. Saat ini dalam layanan Google Translate terdapat dua bahasa daerah Indonesia, seperti bahasa Jawa dan bahasa Sunda. Tidak mungkin Google Translate mampu menyediakan bahasa-bahasa dari daerah lainnya dalam waktu dekat, jika ketersediaan korporat untuk bahasa-bahasa daerah di Indonesia masih sulit ditemukan. Untuk menjembatani kesenjangan antara bahasa umum dan bahasa yang jarang digunakan, dalam hal ini antara bahasa Inggris dan Minangkabau, pendekatan yang lebih cepat adalah dengan membuat Mesin Penerjemah Hibrida berbasis Poros / Pivot-based Hybrid Machine Translation (PHMT) antara bahasa Inggris dan Minangkabau, dengan bahasa Indonesia sebagai poros. Karena bahasa Minangkabau memiliki kemiripan leksikal 61,59\% dengan bahasa Indonesia berdasarkan Automatic Similarity Judgment Program (ASJP), maka dapat di asumsikan bahwa morfologi dan sintaks antara kedua bahasa tersebut juga mendekati. Oleh karena itu, penerjemahan kata-ke-kata antara bahasa Indonesia dan Minangkabau sangat berpotensi untuk diimplementasikan.

\section{METODE PENELITIAN}

\subsection{Tinjauan Sistem}

Berdasarkan hasil analisis penelitian, dapat disimpulkan bahwa Mesin Penerjemah berbasis Augmented reality memiliki dua kriteria. Mesin Penerjemah berbasis augmented reality ini dapat berinteraksi dengan pengguna dengan menerjemahkan teks dari bahasa Indonesia ke bahasa Inggris dan sebaliknya, dan dengan menampilkan suara sebagai hasil terjemahan dan karakter animasi 3D. Mesin Penerjemah berbasis augmented reality adalah tanpa penanda, yang berarti tidak menggunakan marker untuk menampilkan model animasi 3D.

Gambar 1 menjelaskan proses dari input berupa teks hingga output yang berupa animasi objek dan suara hasil translasi dari input.

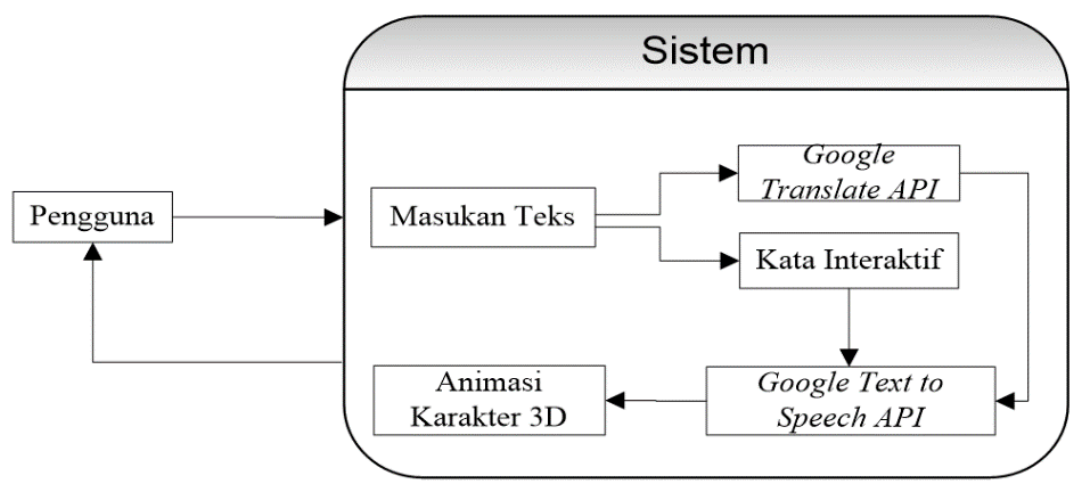

Gambar 1. Desain Logika Program 


\subsection{Kata Interaktif}

Interaktif sendiri adalah hal yang terkait dengan komunikasi dua arah atau suatu hal yang bersifat saling melakukan aksi, saling aktif dan saling berhubungan dan memiliki timbal balik antara satu dengan lainya [8]. Pada sistem ini kata interaktif dikelompokan menjadi dua kategori yaitu khusus dan umum. Saat pengguna mengetikan kata pada aplikasi kata tersebut akan dicocokan pada database jika kata tersebut ada didalam database maka karakter 3 dimensi akan mengucapkan kata interaktif yang ada pada tabel kata interaktif khusus secara acak. Dan sebaliknya jika kata yang diketikan oleh pengguna tersebut tidak ada pada database maka karakter 3 dimensi akan mengucapkan kata interaktif yang ada pada tabel kata interaktif umum secara acak. Pada sistem ini kata interaktif terdiri dari dua bahasa yaitu bahasa Indonesia dan bahasa Inggris. Contoh kata interaktif umum dan khusus dapat dilihat pada Tabel 1.

Tabel 1. Kategori Kata Interaktif Umum dan Khusus

\begin{tabular}{|c|c|c|}
\hline Kategori & Kata Kunci & Pertanyaan Acak \\
\hline Makanan & $\begin{array}{c}\text { Nasi goreng, bakso, ayam goreng, } \\
\text { kentang goreng, telur }\end{array}$ & $\begin{array}{c}3 \text { untuk masing- } \\
\text { masing kata kunci }\end{array}$ \\
\hline Warna & merah, kuning, hijau, biru, putih & $\begin{array}{c}3 \text { untuk masing- } \\
\text { masing kata kunci }\end{array}$ \\
\hline Hewan & ayam, kambing, sapi, kucing, anjing & $\begin{array}{c}3 \text { untuk masing- } \\
\text { masing kata kunci }\end{array}$ \\
\hline Transportasi & pesawat, mobil, motor, sepeda, \\
kereta api & $\begin{array}{c}3 \text { untuk masing- } \\
\text { masing kata kunci }\end{array}$ \\
\hline Buah & anggur, apel, pisang, mangga, nenas & $\begin{array}{c}3 \text { untuk masing- } \\
\text { masing kata kunci }\end{array}$ \\
\hline Umum & None & 5 \\
\hline
\end{tabular}

\subsection{Diagram Alir}

Perancangan aplikasi pada penelitian ini menggunakan flowchart yang digunakan untuk menunjukan alur kerja yang akan dikerjakan oleh sistem secara keseluruhan. Secara umum diagram alur aplikasi Mesin Penerjemah Berbasis Augmented Reality ini dapat dilihat pada gambar 2 dan gambar 3. 


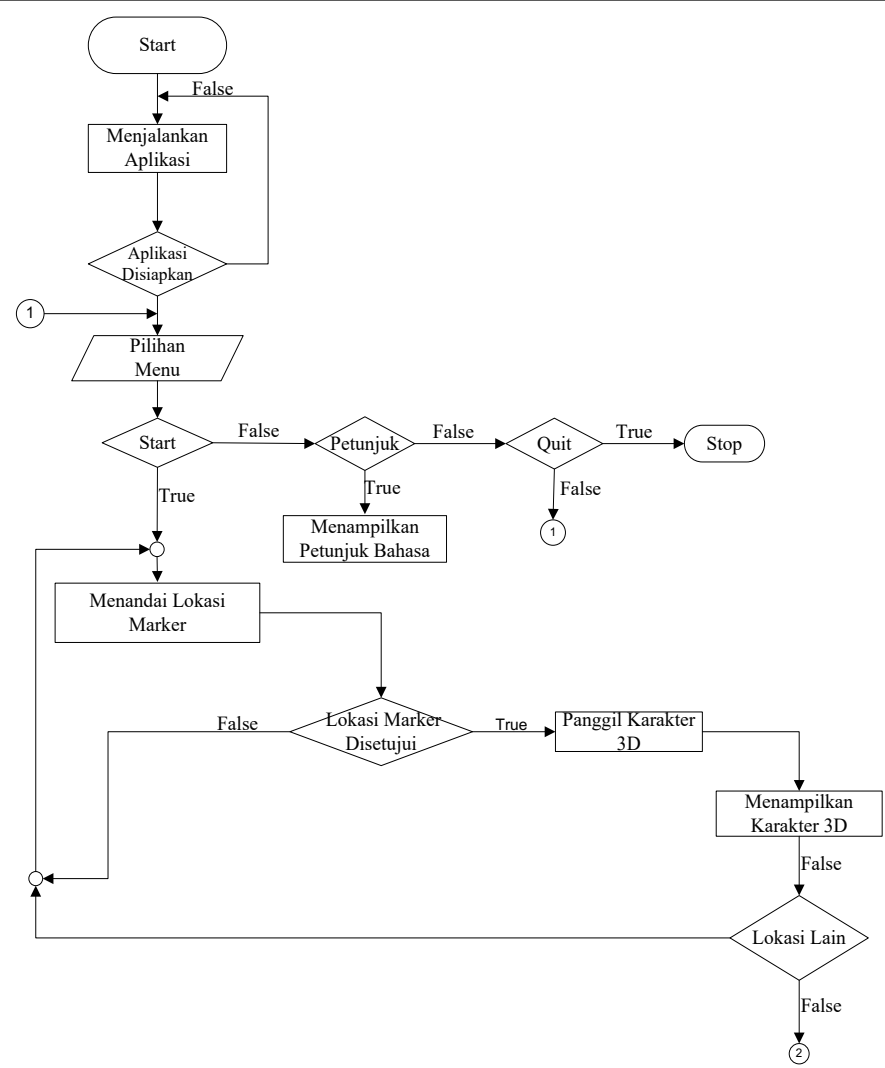

Gambar 2. Diagram Alir Keseluruhan Sistem Bagian 1

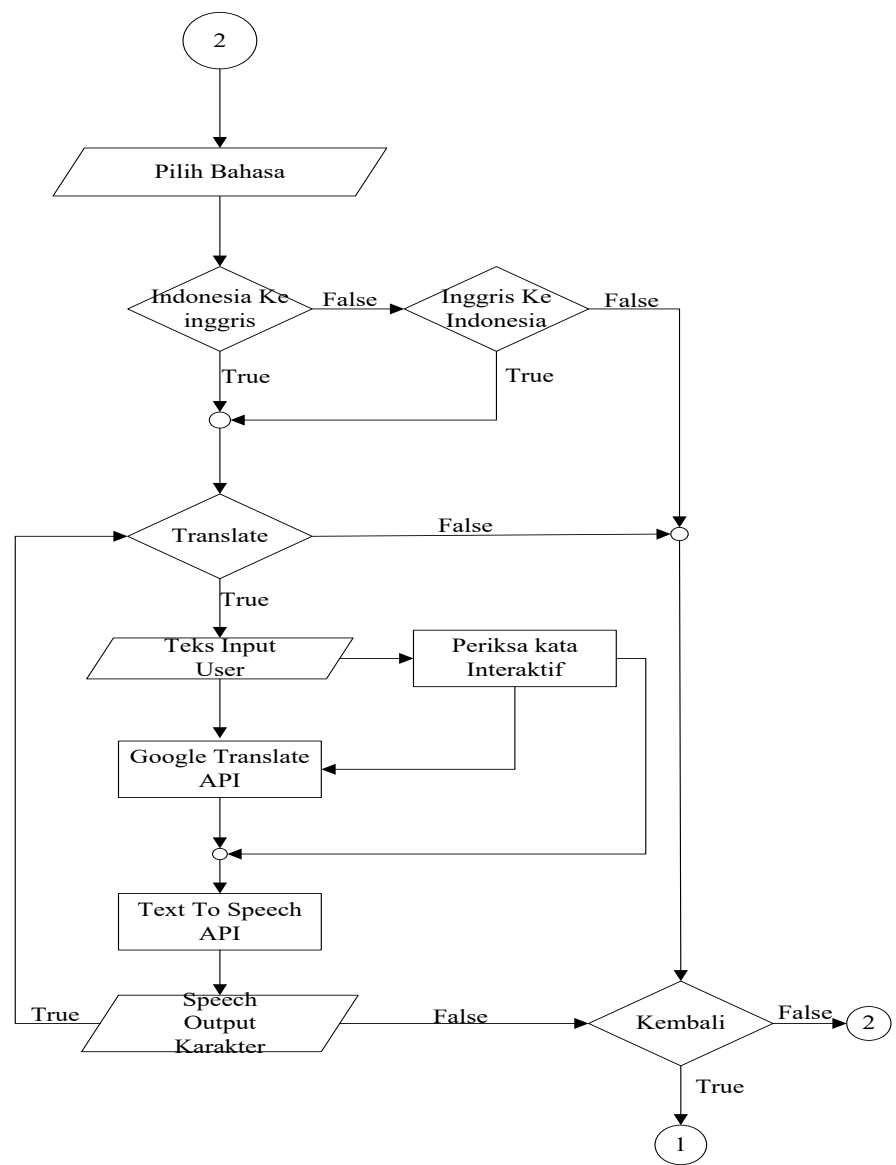

Gambar 3. Diagram Alur Keseluruhan Sistem Bagian 2 
Alur sistem mesin penerjemah interaktif berbasis augmented reality dapat dijelaskan sebagai berikut:

1. User menginputkan teks.

2. Teks akan diperiksa di dalam database.

3. Jika teks ada pada database interaktif khusus maka sistem akan menghasilkan output kata interaktif dalam bentuk teks.

4. Jika pada tahap sebelumnya teks tidak ada pada database interaktif khusus maka sistem akan mengakses database interaktif umum dan menghasilkan output dari kata interaktif umum dalam bentuk teks secara acak.

5. Output kata interaktif akan dikirimkan ke text to speech API untuk dirubah menjadi suara.

6. Karakter akan mengucapkan kata atau kalimat ke pada user sebagai output.

Keterangan alur sistem kata interaktif Mesin Penerjemah Berbasis Augmented Reality tersebut dapat dilihat pada gambar 4.

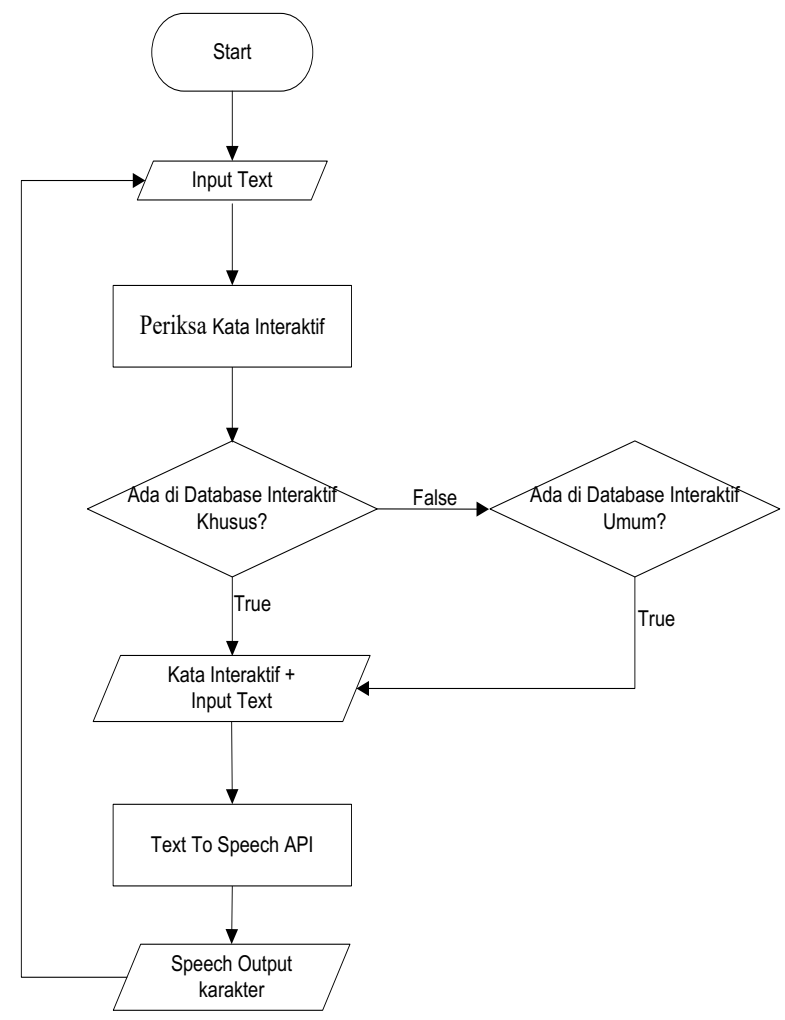

Gambar 4. Diagram Alir Kata Interaktif

\subsection{Cara Kerja Aplikasi}

Mesin Penerjemah Berbasis Augmented Reality ini menggunakan teknik markerless, dimana teknik markerless yang dimaksud adalah marker yang digunakan untuk menampilkan karakter 3D tidak didaftarkan sejak pembuatan aplikasi, melainkan aplikasi akan mencari dan menandai lokasi pada area kamera sebagai marker dan lokasi tersebut didaftarkan sebagai marker untuk menampilkan model karakter 3D. Gambaran cara kerja aplikasi dapat dilihat pada gambar 5.

\section{HASIL DAN PEMBAHASAN}

Berikut adalah beberapa gambar antarmuka dari aplikasi mesin penerjemah dengan animasi $3 \mathrm{D}$ berbasis augmented reality. 


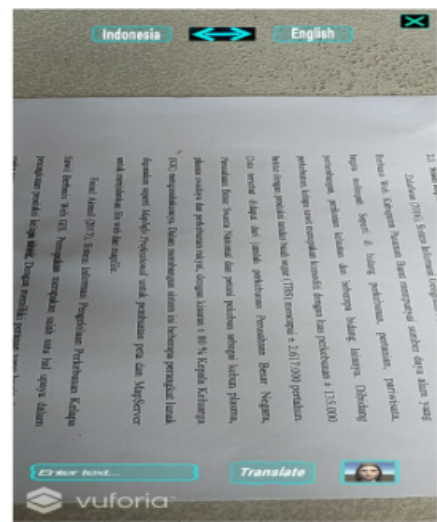

(a)

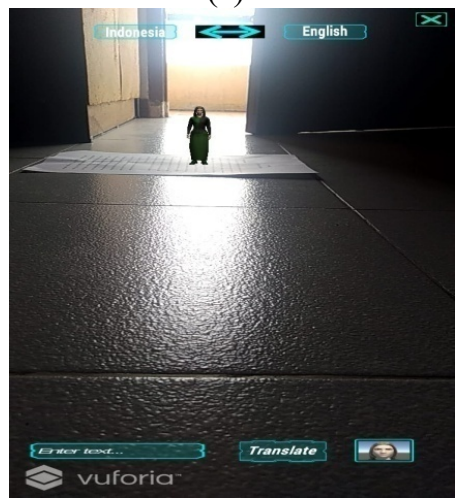

(d)

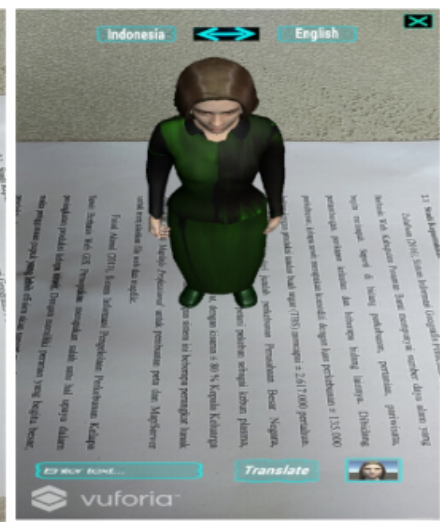

(b)

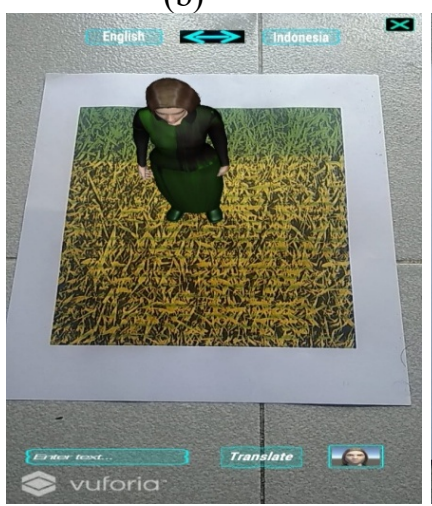

(e)

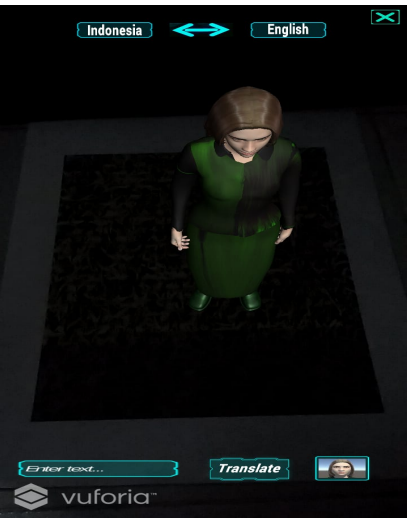

(c)

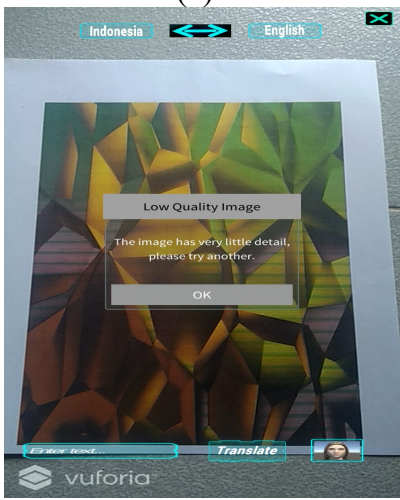

(f)

Gambar 5. Antarmuka Aplikasi

Gambar 5 (a) adalah gambar sebelum animasi 3D ditampilkan dan gambar 5 (b) adalah gambar ketika animasi 3D muncul sesudah pengguna menekan tombol animasi. Pada sub bab ini peneliti akan membahas hasil pengujian dari aplikasi yang telah dibuat. Beberapa pengujian yang telah dilakukan meliputi pengujian intensitas cahaya, pengujian sudut pandang, pegujian jarak, pengujian lokasi pendeteksian markerless, pengujian penerjemahan, dan pengujian kata interaktif.

\subsection{Skenario Pengujian Black Box}

Pengujian black box pada aplikasi mesin penerjemah augmented reality dilakukan untuk menguji setiap fungsi dari input interface yang ada pada aplikasi, sehingga diketahui apakah input interface tersebut sudah sesuai dengan hasil output yang diharapkan. Hasil pengujian black box menunjukkan bahwa semua sistem yang dirancang berfungsi sesuai harapan.

\subsection{Pengujian Intensitas Cahaya}

Pengujian intensitas cahaya dilakukan di dalam dan di luar ruangan dengan intensitas cahaya yang berbeda-beda, pengujian ini dilakukan untuk mengetahui apakah aplikasi mesin penerjemah berbasis augmented reality dapat melakukan tracking dan menampilkan model animasi pada sumber cahaya yang berbeda-beda. Kesimpulan dari pengujian terhadap intensitas cahaya dapat dilihat pada tabel 2. Gambar 5 (c) menunjukkan hasil pengujian di luar ruangan malam hari dengan intensitas cahaya sebesar 28 lux tetap dapat mendeteksi objek untuk diidentifikasi menjadi marker dan menampilkan animasi 3D dengan baik.

Tabel 2. Hasil Pengujian Aplikasi Terhadap Intesitas Cahaya

\begin{tabular}{|c|c|c|c|c|c|}
\hline $\begin{array}{c}\text { Skenario } \\
\text { Pengujian }\end{array}$ & $\begin{array}{c}\text { Kasus } \\
\text { Pengujian }\end{array}$ & $\begin{array}{c}\text { Intensitas } \\
\text { Cahaya }\end{array}$ & $\begin{array}{c}\text { Waktu } \\
\text { Tunggu }\end{array}$ & Hasil & $\begin{array}{c}\text { Hasil } \\
\text { pengujian }\end{array}$ \\
\hline
\end{tabular}




\begin{tabular}{|c|c|c|c|c|c|}
\hline Pencahayaan & $\begin{array}{c}\text { Luar Ruangan } \\
\text { Siang Hari }\end{array}$ & 230 lux & 1 Detik & $\begin{array}{c}\text { Karakter 3D } \\
\text { Tampil }\end{array}$ & Berhasil \\
\hline & $\begin{array}{c}\text { Luar Ruangan } \\
\text { Malam Hari }\end{array}$ & 28 lux & 1 Detik & $\begin{array}{c}\text { Karakter 3D } \\
\text { Tampil }\end{array}$ & Berhasil \\
\hline & Dalam Ruangan & 1130 lux & 1 Detik & $\begin{array}{c}\text { Karakter 3D } \\
\text { Tampil }\end{array}$ & Berhasil \\
\hline & Dalam Ruangan & 322 lux & 1 Detik & $\begin{array}{c}\text { Karakter 3D } \\
\text { Tampil }\end{array}$ & Berhasil \\
\hline & Dalam Ruangan & 0 lux & 0 Detik & $\begin{array}{c}\text { Karakter 3D } \\
\text { TidakTampil }\end{array}$ & $\begin{array}{c}\text { Tidak } \\
\text { Berhasil }\end{array}$ \\
\hline
\end{tabular}

Namun, berdasarkan hasil pengujian intensitas cahaya pada tabel 2, dapat disimpulkan bahwa aplikasi mesin penerjemah tidak dapat melakukan penandaan lokasi atau tracking markerless jika intensitas cahaya bernilai 0 lux, dengan kata lain metode markerless yang ada pada vuforia sdk memerlukan cahaya walau hanya sedikit untuk melakukan tracking terhadap target.

\subsection{Pengujian Jarak dan Sudut}

Pengujian jarak dan sudut dilakukan untuk mengetahui sampai jarak berapa dan pada sudut berapa metode markerless pada vuforia sdk dapat menampilkan karakter 3D, pada pengujian ini dilakukan dengan cahaya terang. Pengujian dilakukan berulang degan jarak minimal $10 \mathrm{~cm}$ dengan sudut $10^{\circ}$ hingga jarak terjauh $60 \mathrm{~cm}$ dengan sudut $90^{\circ}$. Hasil pengujian jarak dan sudut pandang terhadap lokasi dapat dilihat pada tabel 3. Gambar 5 (d) menunjukkan hasil pengujian pada jarak 60 $\mathrm{cm}$ dengan sudut pandang $10^{\circ}$ dimana animasi 3D tetap dapat ditampilkan dengan baik.

Tabel 3. Pengujian Jarak dan Sudut

\begin{tabular}{|c|c|c|c|c|}
\hline \multirow{2}{*}{$\begin{array}{l}\text { Skenario } \\
\text { Pengujian }\end{array}$} & \multicolumn{2}{|c|}{ Aksi Pengujian } & \multirow{2}{*}{ Hasil } & \multirow{2}{*}{ Hasil Pengujian } \\
\hline & Jarak & Sudut & & \\
\hline \multirow[t]{18}{*}{ Jarak dan Sudut } & $10 \mathrm{~cm}$ & $10^{\circ}$ & Karakter 3D Tampil & Berhasil \\
\hline & & $60^{\circ}$ & Karakter 3D Tampil & Berhasil \\
\hline & & $90^{\circ}$ & Karakter 3D Tampil & Berhasil \\
\hline & $20 \mathrm{~cm}$ & $10^{\circ}$ & Karakter 3D Tampil & Berhasil \\
\hline & & $60^{\circ}$ & Karakter 3D Tampil & Berhasil \\
\hline & & $90^{\circ}$ & Karakter 3D Tampil & Berhasil \\
\hline & $30 \mathrm{~cm}$ & $10^{\circ}$ & Karakter 3D Tampil & Berhasil \\
\hline & & $60^{\circ}$ & Karakter 3D Tampil & Berhasil \\
\hline & & $90^{\circ}$ & Karakter 3D Tampil & Berhasil \\
\hline & $40 \mathrm{~cm}$ & $10^{\circ}$ & Karakter 3D Tampil & Berhasil \\
\hline & & $60^{\circ}$ & Karakter 3D Tampil & Berhasil \\
\hline & & $90^{\circ}$ & Karakter 3D Tampil & Berhasil \\
\hline & $50 \mathrm{~cm}$ & $10^{\circ}$ & Karakter 3D Tampil & Berhasil \\
\hline & & $60^{\circ}$ & Karakter 3D Tampil & Berhasil \\
\hline & & $90^{\circ}$ & Karakter 3D Tampil & Berhasil \\
\hline & $60 \mathrm{~cm}$ & $10^{\circ}$ & Karakter 3D Tampil & Berhasil \\
\hline & & $60^{\circ}$ & Karakter 3D Tampil & Berhasil \\
\hline & & $90^{\circ}$ & Karakter 3D Tampil & Berhasil \\
\hline
\end{tabular}

Melihat data hasil pengujian pada tabel 3, dapat diambil kesimpulan bahwa dengan jarak minimal $10 \mathrm{~cm}$ dengan sudut 10 aplikasi mesin penerjemah masih dapat menampilkan karakter 3 dimensi dengan baik, dan dengan jarak terjauh pengujian $60 \mathrm{~cm}$ dengan sudut pengambilan $60^{\circ}$ dan $90^{\circ}$ aplikasi mesin penerjemah masih dapat menampilkan karakter 3 dimensi dengan baik. 


\subsection{Pengujian Jenis Objek Tracking}

Pengujian jenis objek tracking dengan metode markerless ini dilakukan untuk mengetahui objek atau tempat terbaik dalam melakukan penandaan lokasi oleh vuforia sdk dengan teknik markerless. Pengujian ini dilakukan dengan 3 jenis objek. Kesimpulan dari keseluruhan hasil pengujian jenis objek tracking dapat dilihat pada tabel 4. Gambar 5 (e) menunjukkan hasil uji objek tracking pada kertas berwarna dengan banyak detail dimana karakter animasi 3D tetap dapat ditampilkan dengan baik.

Tabel 4. Hasil Pengujian Tracking Objek

\begin{tabular}{|c|c|c|c|}
\hline Skenario Uji & Tindakan Pengujian & Hasil yang Didapat & $\begin{array}{c}\text { Hasil } \\
\text { Pengujian }\end{array}$ \\
\hline $\begin{array}{c}\text { Uji Objek } \\
\text { Tracking } \\
\text { Markerless }\end{array}$ & $\begin{array}{c}\text { Objek kertas berwarna dengan } \\
\text { banyak detail }\end{array}$ & $\begin{array}{c}\text { Model Animasi 3D } \\
\text { Tampil }\end{array}$ & Berhasil \\
\hline & $\begin{array}{c}\text { Objek Kertas Berwarna } \\
\text { dengan sedikit detail }\end{array}$ & $\begin{array}{c}\text { Model Animasi 3D } \\
\text { TidakTampil }\end{array}$ & $\begin{array}{c}\text { Tidak } \\
\text { Berhasil }\end{array}$ \\
\cline { 2 - 4 } & Objek Keybord Laptop & $\begin{array}{c}\text { Model Animasi 3D } \\
\text { Tampil }\end{array}$ & Berhasil \\
\hline
\end{tabular}

Berdasarkan pengujian yang telah dilakukan terhadap objek tracking didapat kesimpulan bahwa vuforia sdk dengan metode markerless tidak dapat digunakan pada semua bidang objek tracking seperti yang tertera pada tabel 4, dikarenakan jika detail objek sedikit seperti yang ditampilkan pada Gambar 5 (f) maka karakter 3D tidak dapat tampil meskipun cahaya dan warna pada objek cukup.

\subsection{Pengujian Beta (End User)}

Implementasi sistem dilakukan dengan memberikan kuesioner kepada 20 orang, dengan tujuan untuk mengetahui tanggapan dari pengguna tentang aplikasi mesin penerjemah berbasis augmented reality ini. Hasil implementasi dengan memberikan kuesioner kepada 20 orang dapat dilihat pada tabel 5.

Tabel 5. Hasil Implementasi Sistem

\begin{tabular}{|c|c|c|c|}
\hline \multicolumn{4}{|c|}{ Jumlah Persentase Koresponden } \\
\hline Sangat Baik & Baik & Kurang Baik & Tidak Baik \\
\hline 4 & 15 & 1 & 0 \\
\hline
\end{tabular}

Secara keseluruhan hasil kuesioner dapat dihitung menggunakan rumus tabulasi untuk mendapatkan hasil persentase dari setiap jawaban kuesioner, masing-masing persentase tersebut adalah sebagai berikut:
1. Sangat Baik $\quad: 4 / 20 * 100 \%=20 \%$
2. Baik $: 15 / 20 * 100 \%=75 \%$
3. Kurang Baik $: 1 / 20 * 100 \%=5 \%$
4. Tidak Baik $: 0 / 100 * 100 \%=0 \%$ 


\section{KESIMPULAN}

Penelitian dan pembuatan aplikasi mesin penerjemah dengan animasi 3D berbasis augmented reality telah berhasil dilaksanakan dan telah dilakukan serangkaian pengujian untuk menguji kemampuan dari aplikasi tersebut. Aplikasi ini tidak dapat mendeteksi objek sebagai marker dan menampilkan animasi 3D jika intensitas cahaya terlalu rendah atau tidak ada cahaya sama sekali. Jarak minimal agar mendapatkan hasil yang baik dalam menampilkan karakter 3 dimensi adalah 10 $\mathrm{cm}$ dari titik lokasi yang ditandai. Pada jarak $60 \mathrm{~cm}$ dengan sudut pengambilan diatas $10^{\circ}$ hingga $90^{\circ}$ aplikasi masih dapat menampilkan karakter 3 dimensi dengan baik. Namun, aplikasi ini tidak dapat menampilkan karakter 3D jika detail pada marker sedikit. Aplikasi ini dapat digunakan di luar maupun di dalam ruangan, dengan syarat intensitas cahaya diatas 1 lux dan marker memiliki banyak detail. Aplikasi ini berpotensi untuk dapat digunakan oleh anak-anak sebagai alat bantu dalam mempelajari bahasa Inggris.

\section{DAFTAR PUSTAKA}

[1] Yamin, Muhammad., 2017, Metode Pembelajaran Bahasa Inggris Ditingkat Dasar, Jurnal Pesona Dasar, vol.1

[2] Pangestika, Galih Vidia., Wikusna, Wawa., Hermansyah, Aris., 2017, Aplikasi Pembelajaran Bahasa InggrisUntuk Murid Sekolah Dasar Berbasis Android, e-Proceeding Of Applied Science, Vol.3

[3] Saputra, Yoga Aprillion., 2014, Implementasi Augmented Reality (Ar) Pada Fosil Purbakala Di Museum Geologi Bandung, Jurnal Ilmiah Komputer dan Informatika, Vol.1

[4] Mariani., Tolle, Herman., dan Ananta, Mahardeka Tri., 2017, Pengembangan Aplikasi Respon Sms Dan Panggilan Telepon Menggunakan Android Text To Speech Dan Proximity Sensor Bagi Pengemudi Mobil, Jurnal Pengembangan Teknologi Informasi Dan Ilmu Komputer, Vol.1

[5] Nasution, Arbi Haza., Safitri, Nesi., Setiawan, Panji Rachmat., dan Suryani, des., 2017, PivotBased Hybrid Machine Translation to Support Multilingual Communication, Department of Information Technology, Vol.22

[6] Nasution, Arbi Haza., 2018, Pivot-Based Hybrid Machine Translation To Support Multilingual Communication For Closely Related Languages, World Transactionson Engineering and Technology Education, Vol.16

[7] Ishida, Toru., Murakami, Yohei., Lin, Donghui., Nakaguchi, Takao dan Otani, Masayuki., 2018, Language Service Infrastructure on the Web: The Language Grid, Institute of Electricaland Electronics Engineers, Vol.51

[8] Maulida, Hidya., 2017, Persepsi Mahasiswa Terhadap Penggunaan Google Translate Sebagai Media Menerjemahkan Materi Berbahasa Inggris, Jurnal Saintekom, Vol.7

[9] Nasution, Arbi Haza., Murakami, Yohei., dan Ishida, Toru., 2017, A Generalized Constraint Approach to Bilingual Dictionary Induction for Low-Resource Language Families, ACM Trans. Asian Low-Resour. Lang. Inf. Process, Vol.17

[10] Dewantara, I Made Adi Yoga., dkk, 2014, Kumpulan Artikel Mahasiswa Pendidikan Teknik Informatika (KARMAPATI), Augmented Reality Book Pengenalan Gerakan Dasar Tari Bali, vol 3

[11] Dikdok., 2017, Naikan Kemampuan Google Translate Hadirkan Neural Machine Translation Untuk Banyak Bahasa, Jurnal Apps, https://jurnalapps.co.id/naikkan-kemampuan-googletranslate-hadirkan-neural-machine-translation-untuk-banyak-bahasa-11334,12 Desember 2018

[12] Hansel Tanu wijaya., 2009, Penerjemahan Dokumen Inggris-Indonesia Menggunakan Mesin Penerjemah Statistik Dengan Word Reordering Dan Phrase Reordering, Skripsi, Fasilkom UI, Depok.

[13] Ilham Efendi., 2014, Pengertian Augmented Reality(AR), IT Jurnal, https://www.itjurnal.com/pengertian-augmented-realityar/, 17 April 2017 
[14] Kurniawan, Didik., Irawati, Anie Rose., dan Yuliyanto, Ardi., 2014, Implementasi Teknologi Markerless Augmented Reality Berbasis Android Sebagai Media Pengenalan Gedung-Gedung di Fmipa Universitas Lampung, Jurnal Koputasi, Vol.2

[15] Nugroho, Adi., 2005, Analisis dan Perancangan Sistem Informasi dengan Metodologi Berorientasi Objek, Informatika, Bandung.

[16] Pamoedji, Andre Kurniawan., Maryuni., dan Sanjaya, Ridwan., 2017, Mudah Membuat Game Augmented Reality (AR) dan Virtual Reality (VR) dengan Unity 3D, Kompas Gramedia

\section{BIOGRAFI PENULIS}

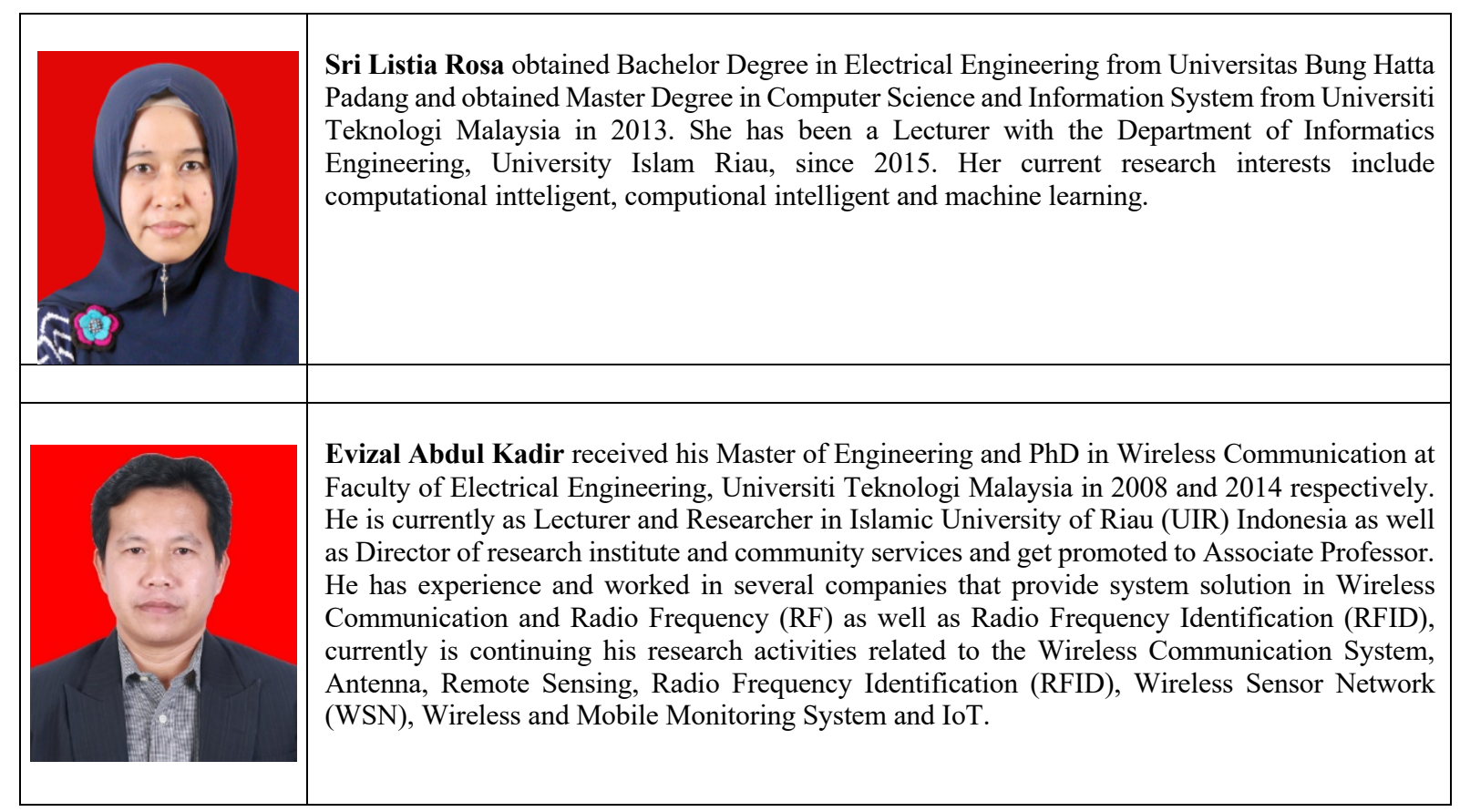

